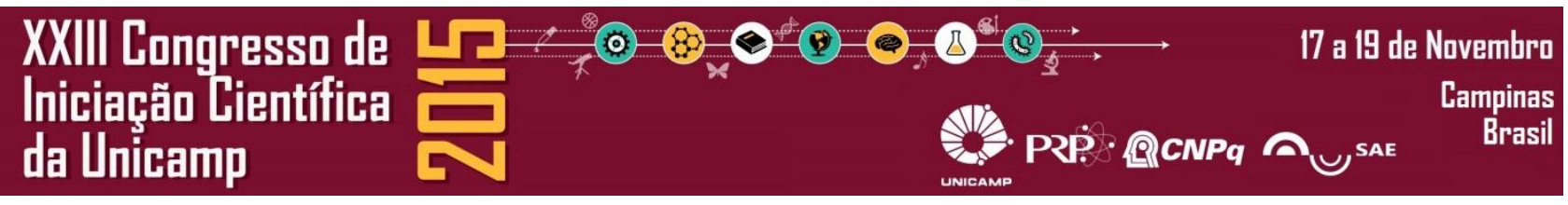

\title{
The enchanted universe and the mysterious existence
}

Pamela de A. C. Leoni (IC)

\begin{abstract}
This scientific work has as an objective the exploration of the symbols of a narrative cosmogony "iorubana" through theoretical and practical research in order to create a refresher through a theatrical performanceperformance. The research culminated in the writing of the dramaturgical text "Floor is Earth. Ceiling is Heaven," based on the works of Mircea Eliade, Pierre Verger, Reginaldo Prandi, Jean-Pierre Vernant and Jacques Lecoq; interviews with actors who already have myths as material of creation and Candomblé practicing; and hands-on labs of actions and languages research.
\end{abstract}

Keywords: Theater, cosmogony, orixás

\section{Introduction}

All mythologies present a picture of the universe around us, a cosmogony. This scientific work has the proposal to explore the symbols of an "iorubana" cosmogony narrative through theoretical and practical research in order to create a refresher through a theatrical performance.

\section{Results and Discussion}

- They were compared one Yoruban cosmogony myth and a Greek cosmogony myth, from registers made by Pierre Verger, Reginaldo Prandi and Jean-Pierre Vernant.

- To adapt the narrative of Yoruban cosmogony present in "african-Brazilian tales and legends: the creation of the world", written by Reginaldo Prandi, to theatrical games and dynamics, a dramaturgical text entitled "Floor is Earth. Ceiling is heaven "has been conceived.

- Practical lab researches were made on the languages clown, buffoon of mysteries and pantomime resulting in the creation of scenic actions for the play "Floor is Earth. Ceiling is heaven."

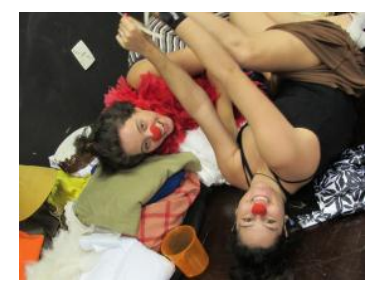

Photo 1: Pamela and Lais in Lab clown research.

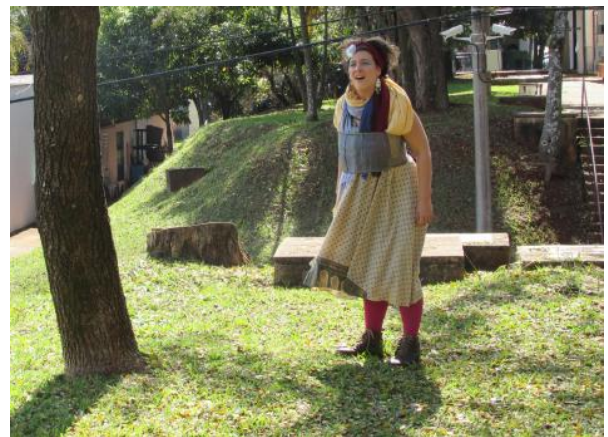

Photo 2: . Pamela Leoni in Lab scenic actions research

\section{Conclusions}

The development of the research has confirmed the relevance of the spreading of african-Brazilian culture and the high potential of cosmogony myths to create theatrical performances

\section{Acknowledgement}

I am grateful to Grácia Navarro for the confidence in my work and $\mathrm{PIBIC/CNPq.}$

PRANDI, Reginaldo., Contos e lendas afro-brasileiros: a criação do mundo - São Paulo:Companhia das Letras 2007.

VERGER, Pierre Fatumbi. , 1902-1996. Lendas africanas dos Orixás/Pierre Fatumbi Verger; [ilustrações] Carybé; tradução Maria Aparecida da Nóbrega - Salvador - Corrupio, 1997.

VERNANT, Jean-Pierre. , O universo, os deuses, os homens/Jean-Pierre Vernant; tradução Rosa Freire d'Agiar. São Paulo: Companhia das Letras, 2000.

LECOQ, Jacques., O corpo poético: uma pedagogia da criação teatral/ Jacques lecoq; com a colaboração de Jean Gabriel Carasso e de Jean Claude Lallias; tradução de Marcelo Gomes, - São Paulo: Editora Senac São Paulo; Edições SESC SP, 2010. 